DOI 10.15826/QR.2015.4.128

Наталья Граматчикова

УДК 821.161.1-94+929(470)

Лидия Енина

\author{
КНИГА О ЛЮБВИ И ВЕРНОСТИ: \\ РЕКОНСТРУКЦИЯ ОБРАЗА ОТЦА-КОММУНИСТА \\ В ВОСПОМИНАНИЯХ ДОЧЕРИ
}

\author{
Natalia Gramatchikova \\ Lydia Yenina
}

\title{
A BOOK OF LOVE AND DEVOTION: A COMMUNIST FATHER'S IMAGE RECONSTRUCTION IN THE DAUGHTER'S MEMOIRS
}

The article is based on S. B. Navarskaya's documentary story The Life of a Soviet Family between the 1930s and 1940s. Stalda Borisovna Navarskaya (1932-2013) calls her narrative a genealogy as it combines seven autobiographies (including her own one and that of her husband). This previously unstudied text came to being because of the writer's need to tell her grandchildren and great-grandchildren about the hard and decent life of their ancestors and was published on the Calameo website shortly before the author of the genealogy deceased. The narration of S. B. Navarskaya, a famous Uralmash engineer and constructor, head of the constructor group for the designing and introduction of the Malyutka small-sized washing-machine only becomes possible and necessary at the time when the bitter lot of the family (exiles, arrests, deaths of starvation, etc.) may become public and perceived as other heroic texts.

The central figure of S. Navarskaya's family and personal history is her father, Boris Stepanov, and the chapter about him is subtitled A Life of a Communist. The article considers an intertwining of a number of discourses that are part of the autobiographic narrative of her father: they are excerpts of her father's diary and his poems chosen by Navarskaya, a number of documents of the epoch (letters, orders, statements, certificates, deeds, etc.), his daughter's frank and sharp language representing her father as a real communist, an ideal father and husband, and also concealed and more often than not unconscious means enabling Navarskaya to keep an idealized image of her own father. Among them is the tabooed reflection of well-known historical events, the interiorization of her father's view of events, etc. The article describes the cultural code of the text introduced into the family history and her daughter's narrative by Navarskaya's mother: the events are commented on by means of poetic quotations and contain allusions to literary works. 
The author analyzes the combination of the writer's father's words about himself and people like him and the peculiarities of his transformation in the biographic narrative authored by his daughter. For Navarskaya the text about her father becomes one about herself too, and may be regarded as the work of an autobiographic memory that lasts as long as its owner's life. The contrast of two types of narrative - that of a father about himself and that of his daughter about him - turn out to be a powerful deconstructing mechanism of the text that tells more than the author initially meant. The text is complete compositionally, as it opens with a pathetic overture for a grave mourning where the possibility of a catharsis is inherently opposed to loyalty and is thus rejected for the sake of the father's memory as understood by the author of the genealogy.

Keywords: family history; communist; scenario; naive author; Berezovo; Kazym rebellion.

Статья написана на материале документальной повести С. Б. Наварской «Жизнь одной советской семьи в 30-е и 40-е годы 20 века». Стальда Борисовна Наварская (1932-2013) называет свое повествование «родословной», объединяя в нем семь биографических текстов (включая собственную автобиографию и автобиографию мужа). Этот текст, не исследованный ранее, появился благодаря ее желанию рассказать внукам и правнукам «о тяжелой и достойной жизни их предков» и был размещен на сайте Calameo незадолго до ухода из жизни автора "родословной». Повествование С. Б. Наварской, известного уралмашевского инженераконструктора, главы конструкторской группы по разработке и внедрению малогабаритной стиральной машины «Малютка», становится возможным и необходимым в тот момент, когда горькая изнанка семейной истории (ссылки, аресты, смерти от голода и др.) может быть предана огласке и принята наравне с героическими страницами.

Центральной фигурой семейной и личной истории С. Наварской является ее отец Борис Степанов, глава о котором имеет подзаголовок «Жизнь коммуниста». В статье рассматривается переплетение нескольких дискурсов, содержащихся в биографическом нарративе об отце: это фрагменты отцовского дневника и его стихи, отобранные Наварской, документы эпохи (письма, приказы, заявления, справки, акты и др.), открытое публицистически-заостренное слово дочери, позиционирующей отца как «настоящего коммуниста», идеального отца и мужа, а также более скрытые, частью бессознательные техники, позволяющие самой Наварской сохранить идеализированное представление о собственном отце. К числу последних относятся табуирование рефлексии относительно известных исторических событий, интериоризация отцовского взгляда на события и др. Раскрывается «культурный код» текста, привнесенный в историю семьи и в нарратив дочери матерью Наварской: события комментируются стихотворными цитатами или содержат аллюзии литературных произведений.

В статье анализируется сочетание отцовского слова «о себе и себе подобных» и специфика его преображения в биографическом нарративе, написанном дочерью. Текст повествования об отце становится у Наварской и рассказом о себе и может быть рассмотрен как результат работы авто- 
биографической памяти, продолжающейся в течение всей жизни ее носителя. Соположение двух типов высказываний - отцовского слова о себе и дочернего слова о нем - оказывается мощным деконструирующим механизмом текста, рассказывающим больше, чем хотел сказать автор. Текст имеет завершенную композиционную структуру, разворачивающуюся от патетической «увертюры» к намогильному плачу, где возможность катарсиса оказывается внутренне противопоставленной верности, а потому отвергается ради памяти отца, как ее понимает автор «родословной».

Ключевые слова: семейная история, образ коммуниста, жизненный сценарий, наивный автор, Березово, Казымское восстание.

Книга биографических воспоминаний Стальды Борисовны Наварской (1932-2013) вызвана к жизни ее желанием передать внукам и правнукам историю своей семьи («одной советской семьи», как уточняет она в названии).

Главная фигура документально-биографического нарратива Наварской - ее отец Борис Африканович Степанов (1907-1942), повествование о котором занимает половину книги. Вторую половину «делят» биографии шести человек: матери Стальды, бабушки и деда по материнской линии, самой Стальды, тетки по отцу и мужа Стальды Юрия Наварского. Фигура отца имеет конструирующее значение для всего личного мира Наварской, хотя он погиб, когда ей было девять лет, и из них более двух лет отсутствовал, будучи под следствием, а позднее - на фронте. Все время отсутствия отца дома семью спасали женщины - мать и бабушка.

В главе, которую Наварская озаглавила «Жизнь коммуниста», звучат два голоса. Один принадлежит самому Борису Степанову (его составляют предоставленные Наварской эго-документы - избранные цитаты из отцовского дневника, фотографии, его стихи и рисунки, списки прочитанной литературы, письма, записки, заявления, приказы и др.), другой - его дочери Стальде. Анализ взаимодействий этих двух нарративов в конструировании образа «идеального коммуниста» и будет составлять нашу задачу.

\section{Особенности композиции: от «увертюры» к плачу}

Биографический текст Наварской об отце выстроен хронологически, части композиции - это «главы семейной биографии», выстроенные в соответствии со сменой места жительства, что глубоко типично для советского дискурса. Она выделяет три периода отцовской биографии: начало карьеры и «конструирования себя» (Тюмень), вершина карьерной лестницы (должность секретаря Березовского районного комитета ВКП(б)) и «падение» (арест, следствие, гибель на фронте). Драматургия отцовской судьбы у Стальды Наварской во многом от- 


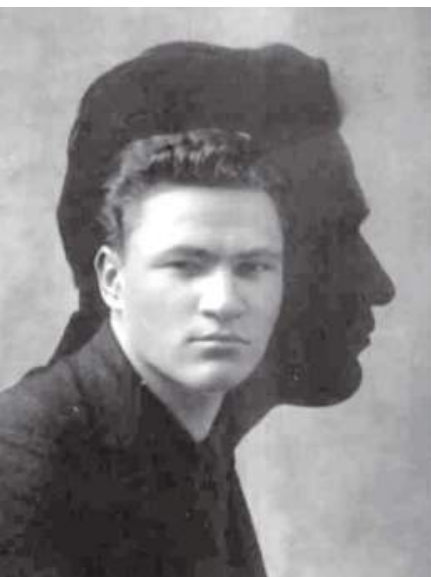

Б. А. Степанов. 1931

ражает драматургию эпохи с ее счастливыми и трагическими случайностями: отец - выходец из крестьянской среды, выдвиженец, активно делающий карьеру «по партийной линии», счастливо женатый, арестованный по доносу, освобожденный после следствия и пыток, подвергнутый остракизму со стороны партии, ушедший добровольцем на фронт и погибший в Ленинграде.

Глава об отце открывается своеобразной «увертюрой», где задается основная интонация повествования. Отец для Наварской - основание родительской семьи, идеал мужчины, отца и мужа («Папа - это воплощение мужественной красоты, верности, честности, надежности и любви!» [Наварская, с. 4] ${ }^{19}$; жизнь с ним - возвращение в рай детства («Папа - это освобождение от забот, горя, голода, маминых слез и надежда на возвращение к беззаботной, мирной и счастливой жизни!» (с. 4)), утрата отца - утрата счастья, происходящая дважды: сначала арест и полтора года тюрьмы, потом гибель на войне через девять месяцев после мобилизации. Рассказ об отце имеет завершенную рефреном структуру, где Наварская дважды - в начале и в конце текста - говорит о магической притягательности отцовского имени: «...Всю жизнь для меня это имя звучит как мучительно-сладкая музыка» (выделения в цитатах здесь и далее наши. - Л. Е., Н. Г.) (там же). Биография отца у Наварской становится рассказом о главной в ее жизни любви. Ее подзаголовок - «Жизнь коммуниста» - помещает образ семейной истории в широкий исторический контекст, задавая масштаб изображения отца как фигуры типической, характерной для 1930-1940-х гг., и продолжая заданную заглавием всей книги обобщающую тенденцию (семейная история типологизируется у Наварской маркером «одной советской семьи»). Стальда Наварская видит отца глазами дочери-жены-матери с доминирующей женской позицией. Такого же эмоционального накала, как в начале, текст Наварской достигнет только в финале при описании посещения ею отцовской могилы на Пискаревском кладбище, куда она впервые смогла приехать в 1958 г. Все, что предшествует этому событию - долгая дорога с пересадками, навязчивые воспоминания о матери и ее недавней смерти, мысли о любви родителей и горе - передано у Наварской тем языком физиологии аффектов, на котором в европейской литературе первой о чувствах заговорила Сапфо. «Нервная дрожь», «свинцовая тяжесть в душе», «неудержимое стремление к могиле

${ }^{19}$ Далее цитаты из повести С. Б. Наварской даются по этому изданию в круглых скобках с указанием страниц. 
отца», «маниакальный порыв» - напряжение, доходящее до аффекта, разрешается у Стальды Наварской в рыданиях на могиле отца. Определяющим для нее становится глагол «пала», в котором она находит полное соответствие своим чувствам, соотнося свое поведение с тем, как, ей казалось, вели себя настоящие русские бабы:

Длинные бугры, заросшие засохшими сохряками, и никого кругом, только низкое тоскливое небо. Я с каким-то облегчением пала, именно пала (хорошее русское слово) на первый же из бесконечных холмов и не из горла, а из груди, из сердца вырвался громкий вопль (выделено С. Наварской. - Н. Г.). Я не осознавала свое поведение, просто в эту минуту проявилась моя русская бабья генетика и заставила меня обнимать эту сырую промерзшую землю и выть, как раненый зверь. Наверное, и мертвым, и живым необходимо такое бурное выражение горя. Оно снимает накопившуюся мучительную боль и облегчает душу (с. 72).

Именно на кладбище находит свое завершение роман Стальды Наварской с отцом, который был в этот момент оплакан ею и как отец, и как муж, и как сын от имени всех поколений женщин ее семьи.

Далее рассказ С. Б. Наварской о каждом из этапов жизни отца предваряется большой цитатой из дневников самого Бориса Степанова.

\section{Дневник Бориса Степанова}

Тюмень: «Хотел встретить волков, твердо веря в револьвер и нож»

Первые фрагменты дневника Степанова датируются январем 1933г., когда он как ответственный секретарь Тюменского горсовета объезжал с партийным инструктажом райкомы, контролируя план хлебозаготовок в Тюменской области. По складу характера это был боец и спринтер («был стремителен и горяч» (с. 11)). В семейной истории работоспособность отца и его жажда жизни объясняются предчувствием ранней смерти:

Мама говорила, что он, видимо, чувствовал, что ему предстоит короткая жизнь, и торопился сделать как можно больше полезных дел, экономя время на сне, отдыхе и даже еде (с. 11).

Самый выразительный в языковом отношении фрагмент дневника 1933 г. посвящен 10-дневной инспекционной поездке. В том варианте описания поездки, какой публикует Наварская, отцом подсчитаны пройденные километры, перечислены населенные пункты, но нет ни одной образной зарисовки тех, с кем общался Борис Степанов, не описано ни одного реального разговора. Все пространство общения с людьми заполнено бюрократическим, «не-своим» словом: 
Руководители хозяйств довольны инструктажом, жалуются, что к ним по этой работе до сих пор никто не приезжал. С моими выводами согласились. Поездкой и своей работой остался доволен, познакомился с хорошими коммунистами. Несколько партийных руководителей за их бездеятельность рекомендовал к снятию (с. 17).

«Собственный» язык у Бориса Степанова появляется в описании ночного бега за санями (бежал, чтобы не отморозить ноги), когда «очень светлой ночью с режущим холодом» «по твердой дороге мои пимы стучали, как железные» (с. 16). Его пытаются остановить («по дорогам много волков, и сама дорога плохая»).

...Но едва ли что-нибудь могло остановить меня. Я отказался. Переобулся. Перевернул стельки и сухим концом перемотал мокрые портянки. Но ноги все равно не согрел. Загнал в свой браунинг восемь патронов, прицепил к боку финку и поехал. Хотел встретить волков, твердо веря в револьвер и нож. Меня подмывало любопытство. Тщетно мы с ямщиком озирались по сторонам, но никакой четвероногий дурак не вышел навстречу (Там же).

В нарративе коммуниста-инспектора «волчья» (=«разбойничья») семантика переходит и на действия самого проверяющего: стремительное появление ночью, из «режущего холода», проверка руководителей и дальнейший бег без возможности поменять одежду, почти без сна. Холод и голод даже усиливают азарт: «Полуторасуточная голодовка укрепляет пищеварение» (Там же). Ассоциативный ряд может быть продолжен вплоть до известных выражений «волка ноги кормят» и «медвежий угол». Степанов олицетворяет собой сгусток энергии и воли, который движется вперед, когда «пимы отказываются, деньги - тоже». Однако результат «инспекционного набега» выражен на удивление бюрократическим языком, а драматические коллизии скорее угадываются, нежели прочувствованы автором:

Хлеба, готового к отправке, накопилось более ста тонн, и дальнейшая его задержка является преступлением. На расторопность директора рассчитывать не приходится. Его как проявляющего оппортунизм уже вывели из состава бюро Исетского райкома партии (Там же).

Высокая уверенность в себе коммуниста Степанова не предполагает рефлексии о «рекомендованных к снятию». Явно, телесно, он борется прежде всего со стихийными и природными силами - холодом, бураном, расстоянием, временем (которое нужно тратить на сон и еду), голодом, вшами, волками. Он ищет врага и сопротивляющуюся среду даже там, где можно было бы избежать противостояния и агона (как нападения волков ночью). Природа - активный участник противостояния, косвенно влияющий и на поведение инспектируемых: 
«Буран портит дорогу, разжижает мозги руководителей» (с. 17). Тем интереснее, что руководители хозяйств оказываются как бы вне этой борьбы: они «жалуются», «соглашаются», «просят», «проявляют оппортунизм», поэтому агональность Степанова фактически не затрагивает, и он не вносит «ничего личного» в их отношения.

\section{Село Березово: «Я полюбил эту могилу»}

Получив должность секретаря райкома партии в Березове, отправившись в «горячую точку», где «трудно и опасно» (с. 18), Борис Степанов открывает «звездную страницу» своей карьеры. В эти годы (1934-1937) Борис упорно занимается «строительством себя». Для самообразования он использует разные источники: Наварская сканирует страницы дневника со списками прочитанных книг, ее отцом подсчитаны пройденные километры, описаны модели самолетов, на которых он летал, и др. С ними соседствуют рисунки оружия и портреты вождей. Принцип каталогизации, своеобразного бухгалтерского подсчета в сочетании с энциклопедичностью в ее схоластическом варианте фиксирует наполнение культурного багажа Бориса Степанова, его искреннюю тягу к всестороннему освоению мира. Новые модели поведения нередко строятся по литературным образцам, при этом новые сценарии соседствуют с более привычными, маркируя воспитание в себе самом «нового человека». Запись 1933 г.: «Постоянное пребывание на улице разжигает во мне желание согреться водкой. Но пока это желание так желанием и остается» (с. 16); запись 1934 года: «...Купил газет, а остальное время слонялся по палубе. Купить бы водки да сидеть в каюте и попивать. Но почему-то не хочется» (там же)). Поиски новых поведенческих моделей могут быть инициированы окружением. Так, страстная влюбленность в Нину Попову (его будущую жену) вызывает в дневнике поток любовных образов литературного генезиса, где он примеряет к своим отношениям с Ниной роли Гайаваты и «Зомбарды милой», «холодного созданья», «матери дочери моей», сравнивая свою служебную машину с пирогой, их жилище - с вигвамом и др. (с. 12). Язык литературных образов - это культурный код, свойственный прежде всего Нине, и лирика Б. Степанова есть в значительной степени способ демонстрации его освоения. Для него умение читать равнозначно умению писать (стихи либо прозу), что свидетельствует и о его авторской наивности, и о степени уверенности в себе. При этом внутренняя жизнь мыслится им, очевидно, как пространство, заполненное «культурным», понимаемым как реально бывшее, типовое и клишированное. Из записей 1933 г.: «В один из моментов раздумья мне пришла мысль написать какой-либо рассказ о себе или о себе подобных» (с. 16).

Жизнь на Севере для Бориса Степанова - время раздумий. Семейное счастье резко контрастирует с драматическими обстоятельствами, сопровождающими его назначение в село Березово (до 1926 г. - город), известное по ссылке в него А. Меншикова и А. Долгорукова, находящееся, по северным меркам, в непосредственной близости от озера 
Нумто, где в декабре 1933 г. произошли трагические события, вошедшие в историю как Казымский мятеж. Для Бориса Степанова произошедшее восстание - не результат трагической глухоты новой власти к культурным особенностям коренного населения этих мест, но подлое и вероломное убийство семерых коммунистов, взывающее об отмщении. Тема мести входит в его стихи и закрепляется в домашнем быту именем лайки Нумто. Особо тяжелое впечатление на Б. Степанова производит поведение некоторых районных коммунистов, прямо обвиняемых им в трусости. В дневнике он многократно называет их фамилии, и Стальда указывает этих людей на фотографиях из отцовского архива. Вообще количество сохраненных в семейном архиве (и Бориса Степанова, и Стальды) имен с «негативной историей» принципиально доминирует над именами «хороших людей» и даже именами «хороших коммунистов». Вслед за «трусом и предателем» семерых убитых коммунистов эго-документы архива перечисляют фамилии тех, по чьей воле и доносам, по мнению Степановых, оказывается под следствием сам Борис, а также тех, кто оставляет без ответа его письма и заявления.

Раздумья о судьбе погибших и примеривание к себе той же участи выражаются у Бориса Степанова в ночных посещениях места их погребения:

По ночам часто хожу на могилу «семи», смотрю на нее, а мысль забегает далеко-далеко, туда, в Казым, на озеро Нумто, где они нашли свой конец. ...Я полюбил эту могилу, она будет вдохновлять меня, когда я устану... (с. 19).

Чувство тревоги в его агональной картине мира находит выход в ненависти к трусам-предателям и к навязываемой ситуацией жизненной стратегии:

Я также готов, как и они, работать и умереть, но не как теленок отдать свою жизнь! В этом я учту их ошибку. Но я им, умершим без сопротивления, клянусь! ...Идейное и огнестрельное оружие надо держать готовым (c. 19).

«Животный страх», в котором Степанов обвиняет струсивших партийцев (особый стыд вызывает то, что хоронили погибших спецпереселенцы, а не соратники), выражается и в предельной эмоциональности записей 1934 г., и во вновь возникшей «волчьей» образности (в противовес «телячьей» жертвенности): «Сквозь зубы, нутром выпирается классовая месть!» (там же).

Обращение на этих страницах дневника к жене («Нинка! Я тебя этим предупреждаю, что и впредь в опасностях и трудностях я буду первым и этого места никому не уступлю» (с. 11)) ставит вопрос о согласованности сценариев преждевременной смерти и семейного 
счастья. В ситуации завещания фраза «я тебя предупреждаю» звучит скорее как угроза, очевидно, потому, что возможность ранней смерти уже осмыслена адресантом. Семейное счастье мыслится возможным только как вторичное по отношению к работе, готовность к смерти становится «простой и страшной истиной», с которой надо «ужиться», так как, «может, с Севера придется возвращаться только одному из нас» (с. 37). Растущая устремленность к последней схватке парадоксальным образом сочетается с отсутствием каких-либо профессиональных коллизий в дневнике (сама Наварская описывает отцовскую работу как поездки в остяцкие стойбища с «повседневной активной агитацией за Советскую власть»). Несмотря на удлиняющиеся списки книг и увеличение количества километров, смерть рядом, она обнаруживает себя в обостренном ошущении хода времени, связанном для Бориса Степанова с особым чувством ответственности на занимаемой им должности, что вызывает невольное любование собой, которое он стремится скрыть под нарочитой грубостью:

Смотрю на свою физиономию. От роду 27 лет, а уже как сорокалетний. Суровость поста губит молодость тела. Мой пост обычно занят людьми на десятка два старше. Вчера исполнилось мне 27 лет. Молодо и старо. Молодо по годам, старо по работе. Мне дают 30-32 года. По роже похоже (Там же).

Напрашивается вопрос о целях и результатах работы, проделываемой столь дорогой ценой, тем более что Борис Степанов жаждет результатов «каждый день, каждый час» - «на Севере это возможно» (Там же). Персонаж дневника Степанова живет на износ на предельно суженном временном горизонте. Глубина изучения им прошлого района - не более пяти лет (с. 36), будущее же «сказочной территории» для Степанова описывается формулируемым им планом. В плане - с помощью рычагов управления (связь, «жилищное и культурное строительство», куда входят «туземный дом» и клуб, «куда бы могли приезжать туземцы, учиться чистоте, гигиене, культуре») и ресурсов (людей «надо таких, которые могут работать самостоятельно») «преодолеть дикость» района. Чаемый результат преобразований в дневнике вновь выражен бюрократическим языком:

Разрешив указанные три вопроса, я беру на себя смелость заявить, что район мы перевернем и выведем в образцовые по области. Так я ставлю лично перед собой. Так буду работать (с. 37).

В каком-то смысле следование Бориса Степанова идее, заложенной во фразе «И как один умрем в борьбе за это» ошеломляет «дословным» воспроизведением заключенного в ней смысла в его судьбе, с непроясненным для него самого «этим», за которое он борется и готов умереть. В публикуемых фрагментах дневника нет никаких 
упоминаний о конкретных изменениях реальной жизни, которые бы секретарь Березовского райкома хотел оставить после себя. Возникает зловещее соседство бюрократической «борьбы за показатели» с ограниченным горизонтом планирования и ежедневными мыслями о смерти, к которым Борису приходится приучать себя. В дневнике он останавливает размышления на тезисе, «что мы вечно жить не можем», поэтому «надо быть безразличным к форме смерти и времени ее» (с. 38). Жизнь покажет обратное: в Советском Союзе время и обстоятельства смерти родителя радикальным образом определяли будущее семьи. Дочь Стальда опровергнет умозаключение отца, сравнивая свою печальную судьбу как дочери погибшего на фронте с худшей участью дочери «врага народа», умершего в тюрьме:

Страшно подумать, что было бы с нами, если бы он остался в тюрьме во время войны: не было бы даже мизерной пенсии мне как дочери погибшего на фронте. Пенсия была 217 рублей, в то время как булка хлеба стоила на рынке 400-500 рублей. Не было бы редко-редко, но все-таки выдаваемых бирок на дополнительные продукты и обувь (с. 61).

\section{Арест и тюрьма: «Жизнь под уклон пошла...»}

Не «дикость Севера» становится причиной крушения карьеры и семейного счастья. Арест Бориса Степанова в октябре 1936 г. происходит по доносу одного из «друзей-партийцев». Вообще энергия сопротивления негативным обстоятельствам в полной мере была свойственна обоим родителям Наварской. Так, отец болезненно воспринимал известия об арестах друзей и написал не меньше десятка писем Сталину. Мать, по словам Стальды, была в ужасе от его попыток (не прекратившихся и после освобождения из тюрьмы) и даже пыталась рвать и выбрасывать письма. Борис Степанов буквально переживает драму депривации, ощущая себя преданным сыном партии, лишенным ее любви и благосклонности (с. 38). В сохранившемся черновике письма соседствуют уверения в любви и прямые обвинения и упреки вождю:

Мы знамя партии... И я люблю тебя. ...Все говорят, что ты был прав всюду. Я же хочу сказать, что ты был и виноват. ...Я у тебя учился принципиальности. Она не только обеспечивает правильность решений вопро$\mathrm{ca}$, но и является главным основным положением в жизни каждого человека. Я не хочу быть моральным и политическим уродом перед людьми и собой (с. 39).

Активное «ты» в переписке принято Степановым как знак единства и равенства всех «настоящих коммунистов»; вместе с тем, оно не позволяет считать Бориса Степанова жертвой системы, а утверждает его сотворчество собственной судьбе. Сочетание несомненной активности его как деятеля и одновременно высокой зависимости от 
штампов и стереотипов эпохи придает не только живость и многомерность образу отца у Наварской, но и дает возможность его интерпретации в парадигме «святости» и «юродства», что частично и осуществляется дочерью.

Первоначально условия его содержания были сносны (в камеpe - шахматы, учебник немецкого, стихи и новые книги). Это время обостренной рефлексии - единственное в своем роде в дневнике. Сомнения как таковые переживаются Борисом Степановым крайне болезненно, воспринимаясь как симптом умирания. В его стихах этого периода раздвоенность, «борьба в себе самом» ощущаются как мучительное нарастание смерти в себе, еще живом и полном сил. Усилия мужа, направленные на доказательство собственной невиновности, поддерживает на воле жена, которую здесь впервые в дневнике Борис называет Ниночкой, предостерегая, как и сокамерников, от негодования как «проявления индивидуализма и отшельничества». Однако самые горячие лирические строки его обращены к партии и к Сталину: это и «бессловесные песни о социализме», куда вкладываются все чувства, призвания, призыв, гордость, радость» (с. 46), и лирика:

Ты поверишь мне, партия, снова,

Сын я верный тебе, а не враг,

За пазуху камень не ложил,

Жизнь и сердце тебе я отдал!

(c. 50).

Рассказывая об этом периоде отцовской жизни, Наварская занимает материнскую позицию, понимая всю наивность отцовских надежд и тщетность усилий, но принимая и любя его таким, каким он был. Лирику отца она никогда не комментирует.

После этапирования из Березова условия содержания изменились разительно: начались многодневные допросы без сна, сопровождавшиеся издевательствами и пытками (отметим, что тема «фашистских зверств» в отделах ОГПУ и НКВД прямо озвучена в письмах Нины Степановой уже в 1938 г.). Чувство опасности рождает у Степанова потребность в концентрации усилий, но точка приложения их вновь оказывается иллюзорной: он готовился к суду, а его не было, вместо этого он под пытками подписал протоколы допросов, содержащих самооговор и клевету на других партийцев. Несмотря на последовавший затем его отказ от показаний, вероятно, донос был пущен в дело.

Весь контекст документов, относящихся к этому периоду жизни Бориса Степанова, производит гнетущее впечатление. И дело даже не столько в методах ведения следствия, о которых известно и по другим источникам, но в ощущении атмосферы тотального взаимного недоверия и неприязни. Так, позже Степановы в заявлениях опишут «действия работников Березовского РК ВКП(б) и следователей по отношению ко мне и моей семье за время моего ареста», назовут фамилии 
следователей и милиционеров и «методы их работы», укажут на заинтересованность доносчика (секретаря РК ВЛКСМ) в получении квартиры Степановых и, следовательно, в выселении семьи, которое последовало сразу за арестом (с. 53-54). Но и сам Борис Степанов не остается в долгу, активно участвует в процессе разоблачения и до, и после тюрьмы, сообщая, например, что его недруг, начальник РК ВКП(б) Сполохов, «в прошлом белогвардеец» (с. 53).

Последние два года жизни Бориса Степанова подтверждают трактовку его поведения Наварской как «надлома», однако это было связано не столько с чувством вины, сколько с невозможностью вернуться к партийной работе. Разрешением этой ситуации для Бориса Степанова стала война.

\section{Свердловск: «неполноценный коммунист»}

Борису Степанову повезло: он вышел на свободу («за прекращением дела»), восстановился в партии, но на «передовую идеологической борьбы» и на Север путь был закрыт. Степанов активно протестует против клейма «неполноценного коммуниста», которое, по его ощущению, наложено на него, он чувствует, что обречен носить «до гроба, как позорное пятно» «исключение и арест, пережитые... по воле некоторых людей» (заявление на имя Маленкова от 27 июля 1939 г.) (с. 60); вновь актуализируется тема возраста («неужели я уже негодный человек, когда мне только 32 года» (там же)). Борис предпринимает многократные попытки вернуться на Север, прописывая мотивировочную часть и сохраняя прежние приоритеты «работа - семья» («имею семью»- «могу ехать один»)*. Однако Север был закрыт для него, а в Тюмени оставаться было сложно, приходилось заново все переживать, «встречаясь с людьми, которые его предали, а некоторые и пытали». В результате семья Степановых переезжает в Свердловск, где надежды на получение высшего образования не оправдываются, и Борису удается устроиться только слесарем на Уралмашзавод. В первые же дни войны он уходит добровольцем (политруком) на фронт. Вероятно, Стальда Наварская во многом права, когда оценивает начало войны для отца как «избавление от мучительных дум». Враг был очевиден, и все накопившееся отчаяние отец перенес на него. Здесь он вплотную подошел к смерти и, получив за полгода семь ранений, погиб при бомбежке в ленинградском военном госпитале (с. 68). После гибели отца в жизни Степановых начинается новый драматически-тяжелый период жизни.

* Вот характерный текст заявления в ЦК ВКП(б) от 14.12.1939 (копия - в Главное управление Северного морского пути): «Мотивирую заявление следующим: 1. Знаю Север. За 3 с половиной года привык к его условиям и люблю их. 2. То, что я был увезен с Севера этапом, под штыком, от работы, которую любил и которой отдавал все, что мог отдать сильный человек, связало меня с Севером, и я обязан вернуться туда. 3. До сих пор справлялся со всеми работами, которые мне поручала партия. Если нужно испытание как бывшему “тюремщику" - могу работать грузчиком в Березово или Игарке. Имею семью: жену и дочь 7 лет. Могу ехать один» (с. 63). 


\section{Образ отца: практика реконструкции}

Биография отца у Наварской, во-первых, мыслится как типологизирующая (о чем говорит и подзаголовок «Жизнь коммуниста»), а вовторых, она открыто публицистична, предельно эмоциональна и наполнена чувством восхищения, преданности и любви. Преклонение перед личностью и биографией отца в соединении с горечью утраты являются основными установками повествования. Поколению первых коммунистов С. Наварская приписывает самые чистые помыслы и патриотические деяния. Она многократно сравнивает отца и все поколение «первых настоящих коммунистов» с «современными чиновниками», у которых «и комфортабельные иномарки, и штат верных прислужников, и бани с девочками, и банкеты с обильными возлияниями, и разнообразные взятки. Честность, порядочность у всех начальников от мала до велика нынче не в моде!» (с. 17). Идеализация образа отца логически приводит к тому, что те, чей жизненный путь был менее драматичным, оказываются недостойными ее признания и уважения: «В горниле $30-$ х годов, во время кровавой битвы с фашизмом, практически все настоящие коммунисты погибли, и на смену им пришли отсидевшиеся в тылу мелкие душонки» (Там же).

Наварская активно использует практику умолчаний либо коррекции нежелательных для нее деталей, то есть находится в позиции активного редактирования части сохраненных документов. Об умолчаниях свидетельствуют избранные страницы дневника, а также лакуны в описании биографий других родственников. Впрочем, возможно, тексты Наварской создавались в разное время, и их неточность и несогласованность есть родовое свойство мемуаров. К примеру, она дважды цитирует фрагменты отцовского дневника, посвященные отказу от алкогольных напитков, и отмечает, что «не помнит, чтобы на столе было спиртное» в Березове, однако в рассказе о дне начала Великой Отечественной войны без каких-либо дополнительных комментариев упоминает, что была одна, так как «отец с мамой ушли в киоск за пивом» (с. 65). В данном случае, разумеется, речь идет об используемых автором техниках педалирования положительных качеств и затушевывания нежелательных, применяемых Наварской-нарратором, а не о том, употреблял ли ее отец спиртное.

Однако в биографии Бориса Степанова есть ряд эпизодов, где коррекция означала бы переосмысление всей роли партии, а значит, и отцовской в происходивших событиях. В таких случаях Стальда Наварская как бы «блокирует» рефблексию, оставаясь верной своей детской памяти и ее вечно длящемуся настоящему, передавая отцовский взгляд на события как собственный. В этом случае для нее «вчера» и «сегодня» совпадают полностью, они сливаются в неком мифологическом вневременном локусе. Особенно ярко это видно в трактовке 
Казымского мятежа. Ее характеристика событий, произошедших на озере Нумто в 1934 г., безусловно, соответствует отцовскому восприятию (мать и двухлетняя дочь ничего не знали о трагедии до своего приезда в Березово). Между тем, неоднозначность ситуации вполне явственна из текста самой Наварской:

Когда мы в марте прибыли в Березов, повстанцы были подавлены и рассеяны по тундре. Но опасность еще присутствовала. С запада, из Коми-Пермяцкого округа восставшим могли оказать помощь многочисленные репрессированные и раскулаченные, сосланные в лагеря. Обстановка готова была взорваться в любой момент! (с. 20).

Изменения в отношении к «раскулаченным и репрессированным», доступность более полной информации о событиях тех лет здесь явно игнорируются дочерью «истинного коммуниста».

Более сложные техники в повествовании Наварской возникают тогда, когда взаимодействуют и чередуются два основных для нее «культурных кода» - отцовский и материнский. Как мы уже видели, нарратив отца состоит в значительной мере из идеологических и бюрократических клише эпохи. Для матери первостепенное значение имеют герои и сюжеты литературных произведений (Нина Попова была художественно и артистически одарена, заведовала библиотекой, ее жизнеописание снабжено ее рисунками, в которых виден острый взгляд сатирика). Спор между отцовской и материнской стратегиями впервые ярко проявляется в ситуации имянаречения дочери.

Мама предлагала заморские имена, вычитанные из мировой классики: Ия, Берта, Дора и др. У отца был совсем другой подход к выбору имени. В это удивительное время множество детей наградили именами Революция, Трактор, Вилена (Владимир Ленин), Станислав и др. Отец нашел имя, которое, по его словам, «носит в себе художественность, результат борьбы всех нас на сегодня и цель на завтра. Это имя СТАЛЬДА!» (с. 15).

Несколько экзальтированная благодарность дочери («Спасибо тебе, папа, за звучное и необыкновенное имя! Оно всю жизнь обязывало меня носить его достойно!» (с. 15)) носит оттенок вызова. Это подтверждение уже принесенной клятвы в верности отцу и его идеалам, руководствуясь которыми, тот выбирал имя. О его точной расшифровке мы можем только догадываться. Здесь интонация Наварской заставляет вспомнить другую клятву в верности - цветаевские строки «Я с вызовом ношу его кольцо!», посвященные С. Э. (Сергею Эфрону). Это стихотворение никак не актуализировано в тексте Наварской, хотя в повествовании о бабушке, например, она прямо обращается к одноименному тексту Цветаевой. У Наварской присутствует похожий комплекс мотивов: верность тому, от кого соблазнительно отречься, апелляция к вечному в противовес «бумажному» и временному; 
любование внешностью, роковой характер гибельной эпохи, «стансы» и «плаха», на которую обречен подобный человеческий типаж. В книге обнаруживается и еще одна любопытная перекличка с людьми из «лебединой стаи»: оказавшись в тюрьме, Борис Степанов просит жену принести ему «Иллиаду» (так!) (с. 38). Вполне возможно, это просто следующий текст в «списке книг для самообразования». Но выбор знаковый, ведь в его ситуации каждая книга могла стать последней. Как известно, ранее «Илиада» в тюрьме стала завершающим штрихом биографии и личного мифотворчества Н. Гумилева, который не расставался с этой поэмой всю жизнь и тоже погиб в 35 лет. Перекличка двух разных судеб здесь не вполне случайна, как не случайна тяга к эпическому батальному полотну у двух этих людей - борцов по натуре, принадлежавших к разным политическим и социальным лагерям. Через поколение после офицеров «белой гвардии» очередь читать «Илиаду» в тюрьме пришла к их противникам.

Наибольшее влияние на характер репрезентации образа отца в повествовании Наварской оказал кинематограф. И внешне, и по характеру отца более всего ей напоминает главный персонаж фильма Ю. Райзмана «Коммунист» (1958). Образ, созданный Евгением Урбанским, был по-своему новаторским и принес актеру всенародную славу и любовь. Неудивительно, что при определенном внешнем сходстве и принадлежности к одному поколению «первых», «настоящих» коммунистов персонаж фильма частично скорректировал детскую память Наварской, которая нередко прямо объединяет героя фильма с отцом: «Такие личности, как герой Урабанского и мой отец, ушли из жизни, потому что они были бойцами, не щадили себя и отдали свои жизни ради счастливого будущего своего народа» (с. 17). Кроме того, фильм вышел на экраны, когда Стальде было 26 лет, и она увидела «своего отца» почти как ровесника (в ее воспоминаниях этот аспект отношений явственно выражен).

Влияние фигуры Е. Урбанского на дискурс воспоминаний об отце глубже и многограннее, чем кажется на первый взгляд. Евгений Урбанский (1931 г. р.) - человек одного поколения со Стальдой и схожей с ней судьбы: его отец, «настоящий коммунист», как называл его Евгений, также был репрессирован и потом выпущен на свободу, но умер рано (как отец Стальды) от рака (как мать Наварской) (ил. 2). Таким образом, и в актеpe, и в персонаже Урбанского Наварская могла видеть близкого ей по духу и времени, а также очень привлекательного внешне и по темпераменту мужчину. Как известно, Евгений Урбанский погиб

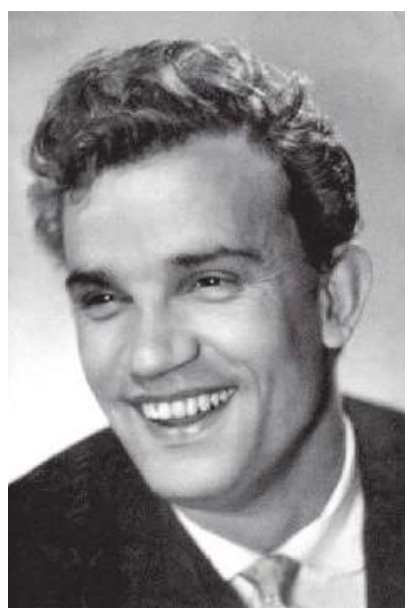

Е. Урбанский. 1957 
в 33 года (Борис Степанов - в 35 лет), живя именно так, как Наварская описывает стиль жизни своего отца - широко, жадно, ничего не откладывая на потом. Это самое поверхностное биографическое сходство. При этом беглый анализ воспоминаний современников Урбанского обнаруживает в качестве ведущей его черты то, чего полностью лишен биографический текст Бориса Степанова невероятное разнообразие поступков, совершенных ради человеческих отношений. Друзья и близкие вспоминают, что Урбанский любил женщин, эффектно за ними ухаживал, был способен на чудачество, геройство, подвиг и поступок; мог выбежать на крик о помощи ночью, в мороз, босиком, влезть на третий этаж по водосточной трубе к любимой и др. Именно этого «человеческого измерения» начисто лишен как текст дневника Бориса Степанова, так и рассказ дочери о нем. Не оспаривая слова Стальды Борисовны, что «при внешней суровости, сухости, требовательности и деловитости он был нежным, ранимым, заботливо любящим мужем и отцом» (с. 17), можно заметить, что этому нет подтверждений в тексте. Декларируемая доброта и человечность Бориса Степанова не воплощены практически ни в одном конкретном примере, за исключением ближайшего семейного круга, где его поведение «хорошего отца» описывается стереотипно. Образ актера Урбанского в какой-то мере служит заместителем отсутствующих в тексте Бориса Степанова качеств человечечности и способствует идеализации отца.

\section{Жизненные сценарии}

Самый драматичный момент, касающийся отца, в воспоминаниях Наварской связан с его арестом и катастрофическим изменением жизни семьи. Эту ситуацию она описывает, пользуясь цитатами и аллюзиями.

Дом в Березове - это место утраченного счастья, в повествовании о нем преобладают описания вкусных запахов, тепла и еды - всего того, чего будет не хватать все остальное время взросления Стальды Наварской (ее сознательная биография, включенная в "родословную», это борьба с холодом и голодом). Большой гостеприимный дом, огромная русская печь, в которой «расшаперивались» душистые кедровые шишки, сотни пельменей из оленины, которые готовили и морозили обе бабушки, самовар и мама, «оживленная от восторженных взглядов летчиков, остроумная, красивая, нарядная». Свет, смех, любовь и флирт, гости, музыка, «веселые голоса беззаботных счастливых людей» (с. 28) драматургически предшествуют резкому слому повествования - аресту и изгнанию из дома. Наварская обращается к цитате из Лермонтова:

Но не со стороны врагов партии надо было ждать беды, она пришла не оттуда, а от друзей-партийцев, которые ели и пили в нашем гостеприимном доме. И вот на «беззаботную семью, как бич, упала Божья кара», сказал бы М. Ю. Лермонтов. Наступил 1937 год (Там же). 
Заметим, что цитата передана с искажением. У Лермонтова в поэме «Демон» читаем:

На беззаботную семью,

Как гром, слетела Божья кара!

Оценочная память Наварской «утяжеляет» лермонтовскую образность, меняя «природный» гром на «падающий бич», акцентируя семантику наказания от высших сил. Какая кара имеется в виду? С одной стороны, обозначен роковой характер 1937 г., но, с другой, в целом религиозный дискурс не свойственен Наварской, и вопрос о каре остается открытым. Вероятно, один из возможных ответов в подспудном признании той доли «трагической вины», которую ощущает Стальда Наварская, на сознательном уровне постоянно траслируя идеологемы отца без «ревизии» и рефлексии, поскольку для нее это равносильно отказу от благодарной памяти о нем.

Второй сценарий перипетии, пережитой семьей Степановых, не озвучен в тексте, но может быть достроен, исходя из заявленного концепта «Божьей кары» и эпохи. Это сценарий известной сказки С. Маршака «Кошкин дом» (1947). Несмотря на неожиданный поворот, рассмотрение семейно-биографического текста с этого ракурса дает интересные результаты. Как мы помним, одним из главных мотивов доноса на Бориса Степанова и он, и его жена, считали зависть однопартийцев. И действительно, в тексте Наварской есть множество деталей, размывающих образ отца-бессребреника. В Березове это уже не голодный инспектор в мокрых замерзших пимах, но глава большой семьи, принявший в самый большой в городе дом семерых родственников, обеспеченный жильем и провизией. Нравы северного городка Наварская не идеализирует: «Березов был маленьким городишком, где отца - секретаря райкома партии - все знали, и многие завидовали моей симпатичной, нарядной и кокетливой маме» (с. 40). Благосостояние семьи остается в тени, но из дальнейшего ясно, что у матери много красивой одежды, которую она после ареста меняет на продукты, пытаясь прокормить себя и дочь после увольнения с работы, да и странствия за арестованным отцом по пересыльным тюрьмам Остяко-Вогульска, Тобольска, Тюмени, Омска требуют средств.

Сказка С. Маршака, как и сказки К. Чуковского, дает возможность разнообразных, в том числе и политических проекций в духе времени. Красивая и богатая хозяйка-кошка во время пожара в одночасье теряет все, оказываясь на улице. Бывшие гости-друзья отворачиваются, и приют она вместе с верным слугой-дворником находит только у бедных племянников. Восприятие пожара в народной традиции амбивалентно: это и проявление Божьей воли («Божья кара»), и зло, которое можно оста- 
новить молитвой. После ареста Бориса Степанова его жену, дочь и тещу выгоняют из дома. Они знают «правила игры» и принимают мгновенно возникший круг отчуждения: «Идти было некуда. В дом к друзьям - завтра арестуют и их» (с. 40). Только в избушке кладбищенского сторожа находят они приют. Показательна трактовка мотивов действий старика-сторожа:

Кто пустит на порог «врагов народа»? Мы дошли до окраины Березова и увидели вдали огонек. Это была избушка кладбищенского сторожа, который не спал и встретил нас с радостью. Ему-то нечего было терять, кроме того, считалось, что этот старичок был немного не в себе. Сторож оживленно захлопотал вокруг нас, напоил жиденьким чаем без сахара, уступил свою кровать (с. 40).

Интересно, что эти редкие человеческие качества - радость непрошеным гостям, желание поделиться всем, что имеет (кровом, чаем, теплом) - немногого стоят для Стальды Наварской, ведь сторож находился на дне социальной иерархии, и «ему-то нечего было терять». Имени этого человека семейная история не сохранила, несмотря на то, что осиротевшие женщины жили у него несколько месяцев. Холод и голод, теснота и отчуждение, завистники и темнота сменяют бывшее царство смеха, тепла и звуков, дружбы и любви. Смысл сказки С. Маршака заключается в том катарсисе, который переживает бывшая заносчивая богачка, обращаясь к ценностям «простой жизни» среди любящей семьи, где в финале происходит переоценка социальных и личных ценностей.

Семейной пьесе Степановых суждено продолжение, но катарсической концовки она будет лишена, придя к тому же финалу через два года после освобождения отца. Характерно продолжение сцены на кладбище, к которой мы уже обращались. Воспоминания Наварской содержат детали, в художественной прозе, несомненно, получившие бы символическую нагрузку: поднявшись с могилы отца, она вновь оказывается в кладбищенской сторожке, где ее жалеют, утешают, поят чаем и предлагают помощь от отца Бориса (!) (местного священника). Однако это фиксируется ею лишь как детали реальной истории и не получает развития в тексте. Сексуальный подтекст встречи с отцом на кладбище продолжает звучать и в описаниях повторных визитов, теперь уже как «минус-прием»: позднее на благоустроенном, ставшем официальным и чужим Пискаревском кладбище она «такого взрыва чувств уже не испытывала». «Навязчивая музыка», «равнодушные туристы»с фотокамерами, «выстроенные в ряд, выровненные, засаженные цветами могилы уже не вызывали того острого чувства отчаяния и горя» (с. 72). Эмоции отчаяния и горя нуждались в выражении и разрядке: «Я скорбно молча постояла около могилы, чуть всплакнула. Я не ощутила чувства облегчения, как при первом посещении, и уходила с кладбища печально неудовлетворенная» (Там же). 
Итак, текст Стальды Наварской об отце хранит абсолютную верность его памяти, идеализируя и пересоздавая тот облик коммуниста 1930-х гг, который выстраивается из его собственных текстов, рисунков и стихов. Попытки рефлексии в данном тексте табуируются автором-дочерью как посягательство на ценность памяти об отце, как опасная ревизия семейной истории. И вместе с тем текст «документальной повести» Наварской сложнее, чем ее открытая публицистическая позиция, ибо настоящая повесть о взаимоотношениях отца и дочери рождается на стыке их нарративов, прорастает из разломов и лакун семейной памяти, что делает текст чрезвычайно интересным. В нем очевидны не только результат влияния эпохи на человека через заполнение его «не-своим» словом, но и обратное - вполне сознательная циклизация, отождествление благодарной памяти и повторения, трансляции прежних установок, поэтому выход из замкнутого круга повтора становится невозможным.

\section{Список литературы}

Адоньева С. Б. Ритуальные площадки // Русский фольклор в современных записях. URL: http://www.folk.ru/Research/adonyeva_ritual_plostch.php?rubr=Researcharticles (дата обращения: 12.09.2015).

Быкова С. И. Дневники 1930-х годов : Terra sovietica incognita // История в эгодокументах : Исследования и источники. Екатеринбург : АсПУр, 2014. С. 117-138.

Воспоминания работницы М. Н. Колтаковой «Как я прожила жизнь» / подгот. текста, предисл., коммент. Б. И. Осипова. Омск, 1997.

Гинзбург E. С. Крутой маршрут: хроника времен культа личности. М. : Советский писатель, 1990. 608 с. Гл. 13. Тараканище. URL: https://www.litmir.co/ $\mathrm{br} / ? \mathrm{~b}=10188 \& \mathrm{p}=158 \#$ section_99 (дата обращения: 12.09.2015).

Головнев A. В. Говорящие культуры: традиции самодийцев и угров. Екатеринбург : УрО РАН, 1995. $607 \mathrm{c}$.

Дашкевич Л., Ларионова М. и др. Повседневная жизнь провинциального имения: дневник слуги уральских помещиков Голубцовых // Quaestio Rossica. 2015. № 1. C. 255-274. URL: http://journals.urfu.ru/index.php/QR/article/view/090 (дата обращения: 12.09.2015).

Дневник священника / подгот. публ. : В. И. Байдин, С. В. Голикова и др. // Урал. историч. вестн. 1995. № 2. С. 114-143.

Ерныххова О. Д. Казымский мятеж : Об истории Казымского восстания 1933-1934 гг. Новосибирск : Сибир. хронограф, 2003. 160 с.

Левитан Л., Разумовская Л. Записки медсестры. Хадера, 2001.

Литовская М. А. Жанр документальной истории семьи как еgо-документ: проблема имплицитного читателя // История в эго-документах : Исследования и источники. Екатеринбург : АсПУр, 2014. С. 55-66.

Наварская С. Б. Жизнь одной советской семьи в 30 -е и 40-е годы 20 века : Родословная одной ветви семейств Наварских, Вайсов, Запорожцев : документальная повесть. URL: http://ru.calameo.com/books/0022066590bc0d68273cc (дата обращения: 12.09.2015).

Новикова В. Пьеса с отточенными коготками // Новая газета. 2014. № 48. 11 дек. Рязанский выпуск. URL: http://novgaz-rzn.ru/nomer11122014_48/1947.html (дата обращения: 12.09.2015).

Новоселов А. Е. Памятная А. Е. Новоселова : Дневник дмитровского купца. М., 2013. $157 \mathrm{c}$. 
Пржиборовская Г. А. Лариса Рейснер. М. : Молодая гвардия, 2008. 496 с. (Сер. Жизнь замечательных людей).

Сандомирская И. Книга о Родине : Опыт анализа дискурсивных практик. Wien : Wiener Slawistischer Almanach, 2001. 286 c.

Степанов Борис Африканович // Ханты-Мансийский автономный округ - Югра : единый официальный сайт государственных органов. URL: http://www.arhivugra. admhmao.ru/wps/wcm/connect/Web+Content/hmao-departments/archive/world-wararchives/voina/memory/world-war-archives-vospominaniya-navarskoi-staldy-borisovnyob-ottze-stepanove-borise-afrikanoviche?presentationtemplate $=\mathrm{Web}+\mathrm{Content} \% 2 \mathrm{Fpt} \_$print (дата обращения: 12.09.2015).

Чуковская Л. К. Записки об Анне Ахматовой : в 3 т. М. : Время, 2013. Т. 3. $1963-$ 1966. 608 c. C. 400.

\section{References}

Adon'eva, S. B. Ritualnye ploshchadki [Ritual Sites]. In Russkiy folklor v sovremennyh zapisyah. Available at: URL: http://www.folk.ru/Research/adonyeva_ritual plostch. php?rubr=Research-articles (mode of access: 12.09.2015).

Baydin, V. I., Golikova, S. V., Dashkevich, L. A. \& Nechaeva, M. Yu. (Eds.). (1995). Dnevnik svyashchennika [Diary of a Priest]. In Ural'skij istoricheskij vestnik, 2, pp. 114-143.

Bykova, S. I. (2014). Dnevniki 1930-h godov. Terra sovietica incognita [Diaries of the 1930s. Terra Sovietica Incognita]. In Istoriya v ego-dokumentah: Issledovaniya i istochniki (pp. 117-138). Ekaterinburg, AsPUr.

Chukovskaya, L. K. (2013). Zapiski ob Anne Akhmatovoy [Notes on Anna Akhmatova]. (Vols. 1-3). (Vol. 3. 1963-1966). 608 p, ill. P. 400. Moscow, Vremya.

Dashkevich, L., Larionova, M., Neklyudov, E., \& Shalina, I. (2015). Povsednevnaya zhizn' provincial'nogo imeniya: dnevnik slugi ural'skih pomeshhikov Golubcovy'h [Everyday Life of a Provincial Estate: A Diary of a Landlords Golubtsovy's Servant]. In Quaestio Rossica, 1, pp. 255-274. Available at: URL: http://journals.urfu.ru/index.php/ QR/article/view/090 (mode of access: 12.09.2015).

Erny'hova, O. D. (2003). Kazy'msky myatezh: Ob istorii Kazy'mskogo vosstaniya 1933-1934 gg. 160 p. Novosibirsk, Sibirsky hronograf.

Ginzburg, E. S. (1990). Krutoj marshrut: hronika vremen kul'ta lichnosti [A Steep Route: a Chronicle of the Times of Personality Cult]. Part 13:Tarakanishhe. 608 p. Moscow, Sovetskiy pisatel'. Available at: URL: https://www.litmir.co/br/?b=10188\&p=158\#section_99 (mode of access: 12.09.2015).

Golovnev, A. V. (1995). Govoryashhie kultury: tradicii samodijcev $i$ ugrov [Talking Cultures: Traditions of the Samoyedic and Ugric Peoples]. 607 p. Ekaterinburg, UrO RAN.

Levitan, L. \& Razumovskaya, L. (2001). Zapiski medsestry' [A Nurse's Notes]. Hadera.

Litovskaya, M. A. (2014). Zhanr dokumental'noj istorii sem'i kak ego-dokument: problema implicitnogo chitatelya [The Genre of Family Documentary History as an EgoDocument: The Issue of the Implicit Reader]. In Istoriya v e'go-dokumentah: Issledovaniya i istochniki (pp. 55-66). Ekaterinburg, AsPUr.

Navarskaya, S. B. Zhizn' odnoj sovetskoj sem'i v 30-e i 40-e gody 20 veka. Rodoslovnaya odnoj vetvi semejstv Navarskih, Vajsov, Zaporozhcev. Dokumental'naya povest'. Available at: URL: http://ru.calameo.com/books/0022066590bc0d68273cc (mode of access: 12.09.2015).

Novikova, V. (2014). P'esa s ottochenny'mi kogotkami [A Play with Sharpened Claws]. In Novaya gazeta, 48, December 11. Ryazansky vy'pusk. Available at: URL: http://novgazrzn.ru/nomer11122014_48/1947.html (mode of access: 12.09.2015).

Novoselov, A. E. (2013). Pamyatnaya A. E. Novoselova : Dnevnik dmitrovskogo kupca [A Collection of A.E. Novoselov's Memories: A Dmitrov Tradesman's Diary]. 157 p. Moscow.

Osipova, B. I. (Ed.). (1997). Vospominaniya rabotnicy M. N. Koltakovoj "Kak ya prozhila zhizn'" [Workwoman M. N. Koltakova's Memoirs How I Have Lived My Life]. Omsk. 
Przhiborovskaya, G. A. (2008). Larisa Reisner [Larisa Reisner]. 496 p. Moscow, Molodaya gvardiya.

Sandomirskaya, I. (2001). Kniga o Rodine. Opyt analiza diskursivnyh praktik [A Book about Motherland. An Analysis of Discursive Practices]. 286 p. Wien, Wiener Slawistischer Almanach.

Stepanov Boris Afrikanovich [Stepanov Boris Afrikanovich]. In Hanty-mansijskij avtonomny'j ogrug - Yugra. Edinyj oficialnyj sajt gosudarstvennykh organov. URL: http:/www.arhivugra.admhmao.ru/wps/wcm/connect/Web+Content/hmao-departments/ archive/world-war-archives/voina/memory/world-war-archives-vospominaniya-navarskoistaldy-borisovny-ob-ottze-stepanove-borise-afrikanoviche?presentationtemplate $=\mathrm{Web}+\mathrm{Conte}$ nt\%2Fpt_print (mode of access: 12.09.2015).

The article was submitted on 24.06.2015

Наталья Борисовна Граматчикова, Natalia Gramatchikova, Dr., кандидат филологических наук, Institute of History and Archeology Институт истории и археологии Уральского отделения РАН, Екатеринбург, Россия of the Ural Branch of Russian n.gramatchikova@gmail.com Academy of Sciences, Ekaterinburg, Russia n.gramatchikova@gmail.com

Лидия Владимировна Енина, кандидат филологических наук, Уральский федеральный университет, Екатеринбург, Россия enina.lidia@gmail.com
Lidia Yenina, Dr., Ural Federal University, Ekaterinburg, Russia enina.lidia@gmail.com 